\title{
BEYOND TECHNONATIONALISM
}


This page intentionally left blank 


\title{
INNOVATION AND TECHNOLOGY IN THE WORLD ECONOMY
}

\author{
MARTIN KENNEY, Editor \\ University of California, Davis and Berkeley Roundtable \\ on the International Economy
}

Other titles in the series:

JASON OWEN-SMITH

Research Universities and the Public Good: Discovery for an Uncertain Future

ANDREW HARGADON

Sustainable Innovation: Build Your Company's Capacity

to Change the World

MICHAEL STORPER, THOMAS KEMENY, NAJI MAKAREM, AND TANER OSMAN

The Rise and Fall of Urban Economies: Lessons from

San Francisco and Los Angeles

SHIRI M. BREZNITZ

The Fountain of Knowledge: The Role of Universities in

Economic Development

MARTIN KENNEY AND DAVID C. MOWERY, EDS.

Public Universities and Regional Growth: Insights from the University of California

MARY LINDENSTEIN WALSHOK AND ABRAHAM J. SHRAGGE

Invention and Reinvention: The Evolution of San Diego's

Innovation Economy

JOHN ZYSMAN AND MARK HUBERTY, EDS.

Can Green Sustain Growth? From the Religion to the Reality of Sustainable Prosperity

ISRAEL DRORI, SHMUEL ELLIS, AND ZUR SHAPIRA

The Evolution of a New Industry: A Genealogical Approach

JEFFREY L. FUNK

Technology Change and the Rise of New Industries 
KAYE HUSBANDS FEALING, JULIA I. LANE, JOHN H. MARBURGER III, AND STEPHANIE S. SHIPP, EDS.

The Science of Science Policy: A Handbook

JERALD HAGE

Restoring the Innovative Edge: Driving the Evolution of Science and Technology

SALLY H. CLARKE, NAOMI R. LAMOREAUX, AND STEVEN W. USSELMAN, EDS.

The Challenge of Remaining Innovative: Insights from

Twentieth-Century American Business

JOHN ZYSMAN AND ABRAHAM NEWMAN, EDS.

How Revolutionary Was the Digital Revolution? National Responses,

Market Transitions, and Global Technology

MARTIN FRANSMAN, ED.

Global Broadband Battles: Why the U.S. and Europe Lag While

Asia Leads

DAVID C. MOWERY, RICHARD R. NELSON, BHAVEN N. SAMPAT, AND ARVIDS A. ZIEDONIS

Ivory Tower and Industrial Innovation: University-Industry Technology Transfer Before and After the Bayh-Doyle Act

MARTIN KENNEY AND RICHARD FLORIDA, EDS.

Locating Global Advantage: Industry Dynamics in the

International Economy

GARY FIELDS

Territories of Profit: Communications, Capitalist Development, and the Innovative Enterprises of G.F. Swift and Dell Computer

URS VON BURG

The Triumph of Ethernet: Technological Communities and the Battle for the LAN Standard 


\section{BEYOND \\ TECHNONATIONALISM}

Biomedical Innovation and Entrepreneurship in Asia

\section{Kathryn C. Ibata-Arens}


Stanford University Press

Stanford, California

(c) 2019 by the Board of Trustees of the Leland Stanford Junior University. All rights reserved.

No part of this book may be reproduced or transmitted in any form or by any means, electronic or mechanical, including photocopying and recording, or in any information storage or retrieval system without the prior written permission of Stanford University Press.

Special discounts for bulk quantities of Stanford Business Books are available to corporations, professional associations, and other organizations. For details and discount information, contact the special sales department of Stanford University Press. Tel: (650) 725-0820, Fax: (650) 725-3457

Printed in the United States of America on acid-free, archival-quality paper

Library of Congress Cataloging-in-Publication Data

Names: Ibata-Arens, Kathryn C., author.

Title: Beyond technonationalism : biomedical innovation and entrepreneurship in Asia / Kathryn C. Ibata-Arens.

Description: Stanford, California : Stanford Business Books, an imprint of Stanford University Press, 2019. | Series: Innovation and technology in the world economy | Includes bibliographical references and index.

Identifiers: LCCN 2018033665 (print) | LCCN 2018040780 (ebook) | ISBN 9781503608757 (electronic) | ISBN 9781503605473 | ISBN 9781503605473 (cloth; alk. paper)

Subjects: LCSH: Biotechnology industries-Government policy-Asia-Case studies. | Technological innovations-Government policy-Asia-Case studies. | Entrepreneurship-Government policy-Asia-Case studies.

Classification: LCC HD9999.B443 (ebook) | LCC HD9999.B443 A7853 2019 (print) | DDC 338.4/76606095-dc23

LC record available at https://lccn.loc.gov/2018033665

Typeset by Westchester Publishing Services in 11/15 Minion Pro

Cover design: Christian Fuenfhausen

Cover illustration: iStock | StudioM1 
In memoriam

Agnes Kazuko Ibata (née Morioka)

Richard Alan Ibata 
This page intentionally left blank 